\title{
Regional Integration and the Evolution of the European Polity: On the Fiftieth Anniversary of the Journal of Common Market Studies
}

\author{
WALTER MATTLI AND ALEC STONE SWEET
}

\section{Introduction}

This special issue commemorates the fiftieth anniversary of the Journal of Common Market Studies. Over five decades, the journal has charted the deep transformations wrought by integration in Europe: of markets and economic organization; law and courts; party systems and interest group politics; and of regulation, both public and private. Along the way, scholarship on the EC/EU gradually turned to the pervasive impact of integration and supranational governance on national structures; to how the various levels of decision making interact to produce and implement policy; and to public opinion, cultural identity and the deep normative questions concerning how to assess the political legitimacy of the EU. Once catering to a relatively small community of specialists, there is now virtually no important strain of social scientific, legal or historical research on contemporary Europe that falls outside the journal's purview. Arguably, JCMS is the most important and successful interdisciplinary forum for the publication of research on any single polity - in this case, the European Union.

Although much has changed, major themes developed in this special issue found expression in the early journal. The first twenty issues (1962-1967) contained articles on voting procedures (Sidjanski, 1962), the state of public opinion on the European Community (Gallup, 1963); the concept and practice of 'supranational' authority (Rosenstiel, 1963; Deutsch, 1963); and supposed distinctions between the process of 'functional integration' and that of federalization (Mitrany 1965). One finds articles examining a 'constitutional crisis' (Lambert, 1966) and a 'crisis of national identity' (Kitzinger, 1967), an attempt to 'model' the EC as a 'political system' (Lindberg, 1967) and assessments of the outlook for monetary integration (Triffin, 1965; Gonzalez del Valle, 1966). The lead article published in the first issue of Volume 1 was dedicated to the European Court of Justice (ECJ) (McMahon, 1962), followed by one on the 'nature and functioning' of the preliminary reference system (Berrios Martinez, 1966). The journal also devoted substantial space to scholarship on regional integration elsewhere: in Latin America (Griffin and Ffrench-Davis, 1965; Navarrete, 1965), Asia (Stonham, 1967) and the Arab World (Diab, 1966).

For this special issue, we commissioned an eclectic mix of articles that would reflect some of the rich diversity (substantive, theoretical, methodological) that today characterizes the study of European integration. We encouraged contributors to develop topics of broad empirical interest, to assess the evolution of the relevant scholarship and to extend analysis, as far as possible, across the life of the EC/EU. Although the articles focus on Europe, we recognize and celebrate the journal's pioneering role as a promoter of research 
on comparative regional integration (CRI). We have therefore devoted a substantial part of this introduction to comparative issues, and we asked contributors, where appropriate, to consider their findings in light of experiments in regional integration beyond Europe.

We made no attempt to set theoretical or methodological priorities, or to cover even the most important sub-fields that comprise the journal's now extensive dominion. While offering a multiplicity of perspectives, the contributions to this issue nonetheless share some important dispositions. The first is a view of European integration as a dynamic process that chronically generates new dilemmas of governance as solutions to prior problems are consolidated as stable institutions and practices. The regime has developed not so much by design, from some specified ex ante moment, but by bricolage, ex post. The various macro-processes that make up integration - economic, legislative and regulatory, judicial, socio-cultural and so on - have been shaped, on a piecemeal basis, by a wide range of actors taking decisions in different arenas at different times. The expansive dynamics of European integration have not been replicated on other continents. Regional experiments elsewhere have been far more constrained, both by treaty design and by the vigilant application of state power. We will consider the European case in its comparative context in the next section.

Although our contributors conceive integration, in part, as that set of interconnected processes through which the EU polity has been constructed, defining what the EU is - as a polity - is not the primary focus of their attention. JCMS, of course, has long been the site of a vigorous debate about the nature of the EC/EU, as it has evolved in complexity and form. In a famous article on blind men and elephants, Puchala (1971) demonstrated that the EC could be described in radically dissimilar ways, depending upon what aspect of the system was being analyzed from what standpoint. The regime has been conceptualized, among other ways, as: a system of 'multi-level governance' (Marks et al., 1996); an intergovernmental cartel dominated by heads of governments and state interests (Moravcsik, 1993); a repository of supranational authority that not only governs, but helps to determine state preferences (Sandholtz, 1996); an amalgam of different forms of the nation-state (Caporaso, 1996); and as a type of federal polity to be compared with other federal states (Von Krosigk, 1970; Swendon, 2004). As discussed further in the second part of this introduction, this debate lurks in the background of many of this issue's contributions (De Wilde and Zürn, Fligstein et al., Mény) but it does not drive the analysis.

Instead, the articles in this issue are heavily informed by theory and method developed in research on general questions of importance. Héritier examines how legislative decision-rules have changed over time, with what effect, in light of generic theories of institutional change. Kelemen mixes models of judicialization and delegation to explain and evaluate the enormous authority the ECJ has accrued. Rittberger shows that the steady empowerment of the European Parliament is embedded in the history and social logics of the parliamentary model itself. And Hobolt treats public opinion as a crucial indicator of the European polity's legitimacy, using the same concepts and methods that her field would use to assess the legitimacy of national regimes.

We could go on, but the point has been made. Our understanding of the EU, however sui generis its history, form and functioning, does not depend on the development of sui generis materials. On the contrary, the most important advances in the field have been made by scholars who are directly engaged with broader disciplinary projects. This special issue provides not only a survey of some of the most important research currently 
being undertaken on European integration, but it also indicates how important EU phenomena have become for the application and refinement of concepts, theory and methods in a wide range of disciplines.

The rest of this introduction takes up these points in some detail. In the next part, we consider regional integration in light of three approaches to CRI: neofunctionalism, externality theory and incomplete contracting. A renaissance of the field of CRI is currently underway, and a coherent theory of regional integration, based on the main elements of these approaches, is rapidly emerging. In Europe, integration has produced a polity that scholars now study more or less as they would the national systems that belong to the EU. This momentous outcome weighs heavily on the articles presented here: contributors treat the EU more as an autonomous, quasi-federal political system than as an international organization, and most evaluate the evolution of the EU in light of the shrinking capacities of the Member States to govern autonomously.

In Part II, we provide an overview of the special issue, focusing on two linked issues. The first concerns institutional change - that is, the process through which EU competences and procedures for decision making have evolved over time (Craig, Héritier, Kelemen, Rittberger and Eichengreen). The second concerns political legitimacy and contestation. As the domain of supranational governance has widened and deepened, as the EU has developed features that are recognizably 'state-like', challenges to the EU's political legitimacy have become a 'normal' part of European politics (De Wilde and Zürn, Fligstein et al., Hobolt, Mény, Rittberger).

\section{Regional Integration in Comparative Perspective}

Integration theory is as relevant today as it was when JCMS was founded. One set of reasons is empirical: virtually every region of the globe is experimenting with new arrangements or reforming existing regimes. Economic globalization is, in large measure, channelled through and registered on regions (Kim and Shin, 2002). Regional integration also raises an important theoretical challenge: how do we explain variation in the design of regional regimes and the outcomes that they have produced? Some integration schemes fail to attain most or any of their objectives, while others are highly successful. In this section, we reflect on these issues by reviewing the main approaches to CRI.

The EU comprises only one case of regional integration, to be understood comparatively. It is of special importance, however, since extensive research on its evolution has generated concepts, hypotheses and methods that presumptively apply to all regional arrangements. The classic questions of European integration, after all, are at the core of CRI. Can integration succeed if states do not confer significant authority to supranational organs, provide for strong monitoring and dispute resolution procedures, or agree to give up their veto by renouncing unanimity decision-rules? Does the mix of intergovernmental and supranational modes of governance change over time, or vary across policy areas, and why? Which actors and processes are crucial to producing the 'demand' for integration, and how and to what extent does the regime respond? Whereas European integration theory provides some candidate responses to these questions, it is also true that CRI helps to illuminate the distinctive features of the EU case.

Three main approaches to CRI stand out: neofunctionalism, externality theory and contracting theory. Each has been developed, in part, through research on European 
integration. The three frameworks overlap one another in important ways; indeed, the most sophisticated theories of European integration have self-consciously combined materials from each approach, at least since the 1990s. We treat them separately here in order to focus attention on the specific arguments to which each gives pride of place.

\section{Neofunctionalism}

Ernst Haas, of course, is the most influential early theorist of CRI. Although primarily interested in understanding European developments, he insisted that his ultimate concern was 'not [to uncover] the uniqueness of this or that region, but with investigating the generality of the integration process' (Haas and Schmitter, 1964). Rising interdependence (especially economic transactions across borders) in a region creates pressure for integration. If and how this demand is actually met, however, is conditioned by three variables which, taken together, explain variation in the intensity of integration: social and political pluralism; symmetrical regional heterogeneity; and bureaucratized decision making coupled with supranational agency. The measure of each of these factors can be high or low: a high value will facilitate integration, a low value will render success less likely.

By high social and political pluralism, Haas meant the full mobilization of society via interest groups and political parties, and elites competing for political survival and dominance under rules of constitutional democracy. Integration proceeds most rapidly when it responds to socio-economic demands emanating from a pluralistic industrial-urban environment.

Because the modern 'industrial-political' actor fears that his way of life cannot be safeguarded without structural adaptation, he turns to integration; but by the same token, political actors who are neither industrial, nor urban, nor modern in their outlook usually do not favour this kind of adaptation, for they seek refuge instead in national exclusiveness. (Haas, 1961, p. 375)

Symmetrical heterogeneity is high if the structure of pluralism among states in the region is similar - that is, classes, political parties and organized interests have counterparts in other states with which they can pursue common cause. Haas hypothesized that symmetrical pluralism in a region would be 'of far greater importance in explaining . . . the success [of integration]' than would be 'linguistic, cultural or religious unity' (Haas, 1967, pp. 319-20).

Highly bureaucratized decision making renders more efficient the interactions among national civil services engaged in policy-co-ordination. Further, to the extent that treaties confer authority on supranational agents to propose and make policy, monitor compliance with agreements and resolve disputes, bureaucratic capacity will also be built at the regional level. National officials will come to rely on experts above the state to mediate among them, to 'construct patterns of mutual concessions from various policy contexts' (Haas, 1968, p. 152), and to 'upgrad[e] common interests' (Haas, 1961, p. 377). To the extent that these predictions hold true, market and political actors are likely to shift some part of their 'loyalties, expectations, and political activities toward a new and expanding centre, whose organs possess or demand jurisdiction over the preexisting national states' (Haas, 1968, p. 5).

With remarkable accuracy, Haas predicted varying outcomes of integration, including failure in Latin America during the 1960s (Haas, 1968). Socio-political pluralism was not 
a given in most of Latin America, where paternalism, authoritarianism and other forms of socio-economic traditionalism hindered the mobilization of interest groups and political parties (Haas and Schmitter, 1964, p. 722). Symmetrical heterogeneity, too, was weak. Industrialists, political parties and trade unionists in one country did not readily establish relationships with their counterparts elsewhere. Decision making in Latin America was also more politicized. Battles between socialism and capitalism, working class and aristocracy, the military and civilian, and church and state continued to rage, leaving the formation of a cadre of dispassionate and pragmatic bureaucrats - the tecnicos - unlikely. Finally, the lack of any meaningful autonomy for supranational agents further limited chances of success. For similar reasons, Haas was also deeply sceptical about the prospects of integration in other regions, including among Arab states (Haas, 1961, pp. 380-82).

One distinguishing feature of neofunctionalism worth highlighting, relative to other approaches to CRI, is its concern with the evolutionary dynamics of integration. Under certain conditions, the argument goes, an inherently expansionary process of integration would be sustained (Haas, 1961). Integration would occur to the extent that: (a) transnational activity and economic interdependence proceeds, revealing both potential to reap joint gains and to deal with the negative externalities created by transnational activity; (b) elites (private actors, firms and public officials) are led to seek regional - rather than national - solutions to shared problems; and (c) regional organs supply governance (in the form of market regulation, procedures for the ongoing production of law and dispute resolution) that satisfied these needs. Haas famously predicted that, through mechanisms of positive feedback among these elements, integration would beget integration, an outcome that he called 'spillover'. The achievement of integration in one policy sector typically produces pressure to integrate in related sectors. ${ }^{1}$

In the 1990s, neofunctionalism was revived, modified and subjected to relatively systematic testing (Burley and Mattli, 1993; Sandholtz and Stone Sweet, 1998). This research has demonstrated that Haasian feedback loops and other forms of spillover have been the basic mechanisms of integration across the history of the EU. Most important, progress in 'negative integration' (the removal of national barriers to exchange across borders) was shown to be causally connected to 'positive integration' (the supply of EU regulations). The most comprehensive account (Fligstein and Stone Sweet, 2002) demonstrated that the activities of market actors, lobbyists, legislators, litigators and judges became connected to one another in specific ways. These linkages constituted a selfreinforcing causal system that has given the EU its fundamentally expansionary features. A wealth of detailed case studies also documented the various forms that spillover takes, across a range of policy areas.

As important, the field was enriched by innovative research that was compatible with, or contributed to, the development of neofunctionalism. These include influential studies on delegation to supranational organs (Pollack, 2003), the historical dynamics of integra-

\footnotetext{
${ }^{1}$ The intergovernmentalism of Garrett (1992) and Moravcsik (1998) also focused on the externalities of economic interdependence, and they drew from theories of contracting, delegation and commitment. Neofunctionalism differs from these theories on theoretical grounds (how axioms are derived). Intergovernmentalists deny the causal importance on integration of the development of transnational linkages and society, and downplay the capacity of supranational organizations to generate outcomes not desired by the dominant states. The theory predicts that the course of integration will be tightly constrained by national interests and intergovernmental bargaining, and that significant 'unintended consequences' (for governments) are never produced. These claims, in our view, have been refuted by the evidence.
} 
tion (Pierson, 1996) and the role of culture and ideas in political projects of market building (Fligstein and Mara-Drita, 1996). Early neofunctionalism also provided several of the key ideas and elements that later approaches to CRI - in particular externality theory and contracting theory - would develop more fully. Haas understood the crucial role that the externalities of economic interdependence play in creating demand for integration. He even noted that the impulse to integrate, even in Latin America and the Arab World, might be triggered by common external threats - an insight he did not attempt to fully theorize (Haas, 1961, p. 382). Externality theory, among other things, tackles this issue head-on.

\section{Externality Theory}

The externality theory of CRI proposed by Mattli (1999) bears some resemblance to the framework proposed by Haas, most clearly in its emphasis on the analytical primacy of sub- and supranational actors. Central to the theory is the concept of cross-border externalities. Different types of externalities have varying impacts on the incentives of economic and political actors to pursue integration. The concept also incorporates, within a single framework, the internal and external logics of integration. The internal logic elaborates the conditions under which integration succeeds or fails; the external logic explicates the conditions under which integration may trigger integrative responses in outsider countries.

The internal logic suggests that two conditions must be satisfied if integration is to succeed - namely demand-side and supply-side conditions. The demand by economic actors (importers, exporters, transnational investors, etc.) for regional rules, regulations and policies depends on the frequency and riskiness of cross-border transactions. Externalities affecting cross-border trade and investment arise from economic and political uncertainty as well as financial hazards that market actors may face when dealing with multiple polities and markets in a region. The costs of these externalities rise as new technologies raise the potential for gains from cross-border market exchange, thus increasing the payoffs to regional rules, regulations and policies that alleviate these costs.

Demand by market actors, however, is never enough. Supply conditions, under which political leaders are willing and able to accommodate demands for integration, need to be satisfied too. Leaders may not see the need to pursue deeper integration if expected marginal gains from further integration are minimal, given the cost in terms of forgone autonomy. The payoff of integration to political leaders is, therefore, crucial.

Even willing political leaders may be unable to overcome collective action problems. Co-ordination problems are particularly salient in integration because most regional integration schemes, including free-trade areas, customs unions or economic unions, go beyond negative integration. The move to positive integration - the development of regional market regulations and other policies - chronically raises distributional issues because any chosen course of action will typically benefit some states within the group more than others (in the EU, see Scharpf, 1988; Moravcsik, 1993). The questions of equitable distribution of the gains from co-operation will need to be addressed to prevent discontent from derailing the integration process. The presence of an undisputed leader a benevolent hegemon - can serve as a focal point for policy co-ordination, and can ease distributional tensions through acting as 'paymaster'. In sum, regimes that satisfy both the 
demand and supply conditions stand the greatest chance of succeeding (for example, EU, Zollverein, North American Free Trade Agreement or 'NAFTA'), whereas groups that fulfill neither set of conditions are least likely to attain any significant level of integration (for example, Latin American Free Trade Association or 'LAFTA', Economic Community of West African States, Arab Common Market); and regions satisfying one but not the other condition show mixed records - some successes but many setbacks (Asia Pacific Economic Co-operation Forum).

Recent studies have applied the theory further. Bouzas and Soltz (2001), for example, have assessed the evolving performance of MERCOSUR in terms of changing parameters of demand and supply; and Krapohl et al. (2010) have examined the relative significance of demand and supply factors in a comparative analysis of NAFTA and MERCOSUR. Other scholars have pointed to a limitation of the framework - namely the narrow conception of leadership as that provided by the dominant country. Laursen (2010) and Tallberg (2006), for example, have stressed - as neofunctionalists do - that supranational institutions can also fulfill the same role, providing policy innovation and reducing policy-based disputes among member states. Further research designed to specify more fully the different mechanisms for overcoming co-ordination dilemmas is needed.

Externality theory complements the internal logic of integration with an account of the external logic, focusing on the effects of regional integration on outsider countries notably in terms of trade and investment diversions. On the crucial issue of how outsiders will react to these externalities, the theory suggests that countries negatively affected by regional integration will pursue one of two strategies. First, they can seek to merge with the group generating the external effects, which is possible only if the existing group is willing to accept newcomers. If the candidate is unlikely to make a net contribution to the union, the union is unlikely to accept it. The union may nonetheless have an interest in accepting an otherwise 'undesirable' candidate when negative externalities originating in an outsider country threatens to disrupt the union's prosperity, stability or security. A dismal economic situation in an outsider country may raise the specter of large-scale migration to the more prosperous union, thus threatening social and political stability. The union may be better off integrating an 'undesirable' outsider in order to invigorate industrial production and employment in the outsider's economy, thereby easing migratory pressure. Following the collapse of communism, the EU offered integration to Central and Eastern European countries, partly for such reasons (Mattli, 1999, pp. 95-9; Schneider, 2009).

Second, if joining the existing regional regime is undesirable or proves impossible, a state may opt to forge a new regional arrangement. The establishment of the EC provoked numerous integration projects - most notably the European Free Trade Association (EFTA) and LAFTA. Likewise, efforts to deepen integration through the Single European Act raised fears of a 'Fortress Europe', provoking a veritable tidal wave of integration projects throughout the world in the late 1980s. Counter-unions, too, must satisfy both demand and supply conditions to be successful.

Externality theory is primarily geared toward explaining, in simple 'comparative statics' terms, why some integration schemes succeed and other fail, and how successful schemes interact with outsider states to structure subsequent attempts at integration. It does not attempt to explain how any governance within a specific regime will evolve over time. 


\section{Contracting Theory}

A third approach focuses on some of the consequences of institutional design, ex ante, on the course of regional integration, ex post. Incomplete contracting will produce a treaty that sets general priorities and objectives for the regime, while leaving many key provisions, such as those specifying the means of achieving the treaty's purposes, relatively open-ended. The more incomplete a regional treaty, the more it will be subject to continuous gap-filling, as well as formal revision, if integration is to proceed. In contrast, a treaty drafted to obtain as much completeness as possible will be comprised of detailed, even fully specified, provisions. To the extent that adaptation is required, it will occur through the same kind of inter-state bargaining that gave birth to the original treaty.

The EU and NAFTA embody this contrast. The Treaty of Rome of 1957, the EU's foundational agreement, is a classic example of an incomplete contract. The text is brief and short on details; its scope, however, is wide. The Treaty also creates the Commission and ECJ, whose decisions in crucial areas are insulated from reversal by the member states, except by treaty revision under a unanimity rule. The implication is that the contract will be 'completed' over time and in light of changing circumstances, through the activities of supranational organs, interacting with affected interests and governments. For example, the ECJ's impact on market, political and legal integration has been extensive, profound and largely unanticipated by the contracting states (literature surveyed in Stone Sweet (2010); see also Kelemen and Craig in this issue). Alternatively, the NAFTA agreement shows all the hallmarks of a relatively complete contract (Abbott, 2000). It is thousands of pages in length, and highly detailed. Yet its aim is limited to establishing a free trade area. Tellingly, NAFTA does not provide for the equivalent of a Commission or ECJ. Instead, it is a regional integration scheme whose central mode of governance is intergovernmental.

What explains these differences? Cooley and Spruyt (2009), who have offered the most sustained application of contracting theory to CRI, emphasize two variables: relative (a)symmetries in power and the demand for integration, among regional states. In NAFTA, the distribution of power is highly asymmetric. The United States occupies a hegemonic position, its economy accounting for about 85 per cent of the NAFTA region. For Cooley and Spruyt, a hegemon poses foreseeable risks for small states, like Canada and Mexico. If elements of the contract are left unspecified, the United States might be tempted to use its power to obtain advantage in future changes to the agreement. A relatively complete contract serves as protection against such risks, leaving residual rights of control (to modify the treaty after its entry into force) with the contracting states, thereby giving all signatories a say in future alterations of the agreement. In theory, small states can pursue an alternative strategy: they can agree to an incomplete contract with a dominant state, while insisting on assigning residual rights to strong supranational organs to guarantee the credibility of commitments made. Cooley and Spruyt (2009, p. 175) argue that American hegemony itself made this strategy unlikely in the North American context. Not only had 'Washington signaled strict limits as to how far it would allow its sovereignty to be curtailed, [but] even if the US had consented to greater delegations to supranational institutions', its dominant position would mean that the smaller states could have little faith that the United States would comply with supranational decisions. In the 
end, American opposition to supranationalism left Canada and Mexico with little choice but to seek protection through completeness.

Why did the signatories of the Treaty of Rome agree to an incomplete contract with provisions for supranational institutions? According to Cooley and Spruyt (2009), the answer once again lies in the distribution of power among states, and the nature of demand for European integration. In the late-1950s, France and Germany maintained an uneasy balance of power on the European continent. Germany needed the EU to reconstruct itself economically and regain political respectability; and France viewed the EU as a means of monitoring and controlling how a rising Germany would develop. The smaller states of the Benelux (Belgium, Netherlands and Luxembourg) also saw benefits; traditionally highly trade-dependent, they stood to gain from easy access to large neighbouring markets. Thus, the demand for integration was broad and strong. The small states nonetheless had reason to worry that France and Germany would seek to use their power to shape the agreement to their benefit in the future. The three Benelux states could therefore agree to contractual incompleteness only on the condition that supranational institutions would be created to safeguard their positions. France (to bind Germany) and Germany (to secure its rehabilitation as a 'normal' state) supported the creation of the Commission and the Court. For Cooley and Spruyt (2009, p. 161), the symmetry of power between France and Germany, and the rise of mutual economic interdependence, led 'political and social elites' to negotiate a treaty that combined 'a significant degree of supranational decision-making with relatively low levels of [legal] precision ex ante'.

Cooley and Spruyt also consider the consequences downstream of different types of contracting. Incomplete contracts that assign residual rights to supranational institutions create the conditions and incentives for further integration, as extensively shown by research in the neofunctionalist tradition (Mattli and Slaughter, 1998; Sandholtz and Stone Sweet, 1998). Relatively complete contracting, by contrast, virtually precludes such developments.

Cooley and Spruyt's framework raises several questions that are internal to the theory. First, does a complete contract actually provide greater assurance to small states against future abuses by the powerful? Suppose the hegemonic state seeks to change a treaty ex post. If the small states depend more on access to the market of the hegemon for their prosperity than the dominant state depends on their markets, the hegemon could credibly threaten to walk away from the agreement if the small states resist changes. Similarly, assume that a few small states are desperate for an integration agreement, while the dominant state is willing only to offer an incomplete contract without supranational institutions. Will the small states reject the offer? At present we are unable to determine whether complete contracts are in fact more robust safeguards than supranational institutions. Research designed to explore the boundary conditions of the relative effectiveness of these alternatives is obviously needed. Finally, the Cooley-Spruyt version of contracting theory can tell us little about how supranational authority is designed, or how it will operate, without being supplemented by other materials. In EU studies, delegation theory - based on the adaptation of principal-agent and trusteeship models to the EU case - has become standard (Majone, 2001; Pollack, 2003; Thatcher and Stone Sweet, 2002). As neofunctionalists stressed, supranational organs are unlikely to be effective if they are deprived of continuous contact with private, non-state actors, and if their decisions can be easily overturned or usurped in other ways. The striking 
effectiveness of the EU's legal system, for example, derives in large part from its ability to build transnational alliances with private actors that have a vested interest in market integration and rights protection (Keleman, in this issue). Such networks make interference in judicial proceedings costly even for the most powerful governments, and their efforts to constrain the Court have been starkly unsuccessful (Stone Sweet and Brunell, forthcoming). Effective commitment devices can develop in regions characterized by asymmetries in state power.

\section{The European Polity}

Integration has produced a complex quasi-federal polity in Europe, but not (yet) elsewhere. This raises particular challenges for those seeking to understand the evolution of the EU - on its own or in comparison with other regional regimes. This special issue takes up these challenges, two of which we emphasize here. First, as integration has proceeded, EU institutions have been continuously subject to change, both incrementally, through use and adaptation, and through rounds of formal negotiation. The second concerns legitimacy dilemmas, which have become more acute as the impact of the EU on people's lives has become more pervasive.

Several of the contributions to this issue reflect what we view as a productive trend in the social sciences more generally: theories of institutional change have become much less sectarian and more inclusive methodologically. Scholars now accept that compelling and fruitful theorizing often necessitates the blending of insights from a variety of theoretical traditions. Historical institutionalists, for example, have moved to complement models of path dependence and punctuated equilibrium with elements drawn from traditional powerdistributional theories (Thelen, 2004; Peters et al., 2005; Hall, 2011). In the same spirit, Jupille et al. (forthcoming) have integrated otherwise disparate accounts of institutional use, selection and change within a single dynamic analytical framework on institutional choice. They include power, efficiency and distributional motives as key drivers, and replace the assumption of synoptic rationality with a more realistic bounded-rationality assumption favoured by research in sociology and new institutional economics.

We sketch here an expanded version of the traditional demand and supply framework, the implicit or explicit workhorse in much analysis of institutional change, in order to locate the contributions to this special issue that explain change in the EU. Demand focuses on the deep causes of change. These can typically be traced to new technologies or other exogenous events that weaken the functional fit between an existing governance structure and the set of co-operation problems that the structure was meant to resolve. Exogenous events alter the stakes, complexity and intensity of a co-operation problem, triggering demand for an overhaul of the institutional status quo. Supply focuses on the actors and procedures involved in shaping the response to this challenge. Because different solutions have different distributional implications, the preferences of the actors negotiating specific modalities of change may vary considerably. In bounded-rationality contexts, the distributional stakes are often not immediately apparent, which may facilitate agreement. With use, however, the distributional implications of reform become clear, and groups whose relative power has weakened will regret having acceded to the agreement. The supply-side analysis seeks to explain why some groups prevail over others, and why institutions therefore come to look and operate the way they do. 
The key to a more synthetic approach to supply-side analysis is a more comprehensive understanding of the sources and implications of bargaining power. We can distinguish four main sources of power: material and financial; informational and knowledge-based; normative and ideational; and institutional. Analysts often give primacy to only one source, ignoring the others, although we know that actors frequently derive power from multiple sources. Consider, for example, the powers of the justices serving on the ECJ, a prominent set of actors in many of the studies in this special issue. First, they have great institutional power: the ECJ is a focal organ of governance, single and uncontested; in addition, it is supported by a wide range of 'natural' clients and allies, including the Commission, domestic courts and powerful socio-economic groups with a vested interest in integration. As a result, the depth and breadth of the ECJ's patronage network' is considerable. Second, the ECJ possesses extensive normative and informational power (Burley and Mattli, 1993). The Court's duty is to interpret and apply - authoritatively EU law, as well as to enforce that law against the Member States, and it does so in their its own 'doctrinal' language. The Court routinely camouflages activist interpretations and controversial decisions in technical legal garb (Mattli and Slaughter, 1998).

In this special issue, several studies beautifully illustrate the significance of various sources of power for understanding the supply and evolution of institutions. Rittberger explains why the European Parliament (EP), an organ possessing few nominal powers at the outset, developed into a lawmaker on an equal footing with the Council of Ministers in the legislative process. When the Treaty of Rome was negotiated, the Benelux countries took the view that their interests could more effectively be protected in an intergovernmental Council, where every Member State had veto power, than in a parliamentary body. A weak EP was the result. How and why did the EP's legislative role increase? Rittberger's main proposition is that 'actors whose preferences are in line with the standard of legitimacy tend to have superior bargaining power [relative to] . . . actors whose preferences cannot be easily squared or brought in line with the standard of legitimacy argumentatively'. The introduction of qualified majority voting (a response to the declining competitiveness of the European economy and enlargement dynamics) meant that any national government could be outvoted, undermining the capacity of national parliaments to (indirectly) control EU legislation. Those in favour of a much more substantial EP (mainly MEPs and a few sympathetic governments) seized on this 'legitimacy gap' to successfully push through an extension of the EP's powers. Invoking the deeply rooted legitimacy standards of parliamentarism put opponents on the defensive, maginalizing and 'shaming' them as undemocratic.

Heritier's article nicely complements Rittberger's account, tracing the striking evolution of the EP's role in the comitology system. Many EU statutes are incomplete contracts. Under the Single Act, the Council routinely delegated to the Commission powers to take further implementing measures to 'complete' them. The Commission does so under rules known as 'comitology procedures'. Initially, the EP played no role in the comitology system. Today the EP shares with the Council the authority to control outcomes produced by comitology. How did the EP come to gain such influence? Heritier's account stresses the role of uncertainty about the impact of institutional choices in a bounded-rationality context 'where many actors with diverse preferences are involved'. The introduction of co-decision legislative procedures (the Maastricht Treaty) gave the EP, in effect, a veto over legislation. The EP learned to leverage the veto in order to gain oversight authority 
over the comitology process; it could make approval of EU statutes contingent on the acceptance of its demands to exercise oversight functions. The EP thus succeeded in incrementally carving out a significant new role in an area of institutional design that the Maastricht Treaty had not foreseen.

Kelemen discusses another fascinating transformation: the rise of judicialized governance in the EU. Eurolegalism replaces more informal and opaque approaches to regulation at the national level with EU regulatory regimes that are characterized by formality, transparency, adversarial approaches to enforcement and judicial review. The judiciary stands out as a key engine of this transformation. As Keleman argues:

[T]he ECJ, given its institutional self-interest as a court and its consistent preference for promoting deeper European integration, has embraced this mode of governance more than any EU institution. EU policy makers have invited the ECJ and national courts to play an important role in regulation, but the ECJ has seized on this opportunity and promoted judicialization to an extent that other policy makers did not anticipate.

As noted above, this proposition is consistent with neofunctionalist analysis, and it focuses our attention on the importance of judges in interpreting and enforcing incomplete contracts. $^{2}$

In his article on the development of the principle of subsidiarity, Craig draws on similar concepts. The subsidiarity principle was enshrined in the Maastricht Treaty and reinforced in the Lisbon Treaty. It lays down the rule that if the desired regulatory or policy objective could be 'sufficiently' achieved at the national level, then it is incumbent on the EC to show that the objective could be 'better' accomplished at the Community level. For reasons that each of the three approaches to CRI surveyed in the previous section would predict, the Member States have neither been able to delineate, in a stable way, the respective spheres of authority of the EU and the Member States, nor to curtail the 'creeping competences' of the former (Pollack, 1994; Swendon, 2004). The subsidiarity principle means to respond to both problems. As Craig puts it, "the "S" word [subsidiarity] in the Maastricht Treaty was... important in allaying fears about the " $F$ " word, federalism'.

Strikingly, Craig finds that in the twenty years since the Maastricht Treaty - a period during which thousands of regulations, directives and decisions were passed - fewer than a dozen legal challenges based on subsidiarity have been brought. Why so few? The key reasons accord with neofunctionalist insights. First, many powerful private actors oppose a robust application of subsidiarity on efficiency grounds. To leave substantive aspects of the regulatory regime or enforcement to national governments risks creating regulatory diversity (for example, in health and safety), raising uncertainty and costs for producers and traders. These groups are likely to pressure governments against subsidiary challenges, as well as to urge the Commission and ECJ to plug gaps and fix inconsistencies in regulation and enforcement. Insofar as they are successful, the level of EC control and oversight will be ratcheted up. Second, diverging Member State preferences undermine European governments' ability to resist ongoing EC empowerment. 'In assessing the

\footnotetext{
${ }^{2}$ The implications of the analyses of Rittberger, Héritier and Kelemen for CRI scholarship are straightforward: insofar as regional integration maintains strictly intergovernmental decision-making rules, there is little scope for the kind of institutional transformation that the EU has recurrently undergone.
} 
judicial record,' Craig argues, 'it is important to recognize that in a number of . . . cases the subsidiarity challenge was opposed by other Member States.'

Eichengreen's study provides a particularly timely illustration of the key role played by politics in institutional analysis. The article charts some of the major changes in European governance in response to the global financial meltdown and the euro-crisis, including the European Stability Mechanism (ESM). His investigation makes crystal clear that theories of institutional choice based on economic factors alone are bound to be inadequate in that they miss the supply-side. What is crucial, he notes, is 'the bargaining not just among national governments but also among interest groups within individual Member States', dynamics that are not well captured by 'the simple median voter model used [by economists] ... to analyze the conduct of policy in Europe's monetary union'. Economic crisis created the demand, but supply-side politics will determine the final shape of the response and the accompanying institutional reform. Eichengreen shows that such supply-side politics blocked much-needed moves to fiscal federalism at the EU level in the 1990s, and predicts that they will continue to prevent it from emerging in the foreseeable future.

A second theme of this special issue concerns the socio-political legitimacy of the EU. In their contributions, Hobolt, De Wilde and Zürn, and Mény suggest that the "permissive consensus' - claimed to have enabled an elite-driven, relatively depoliticized integration process to succeed through the 1980s - has been destroyed (Hooghe and Marks, 2009). Haas and his associates had predicted that successful integration would inevitably implicate issues of citizenship and identity (see also Fligstein et al.; De Wilde and Zürn). So it has come to pass. Today not only do scholars and publics evaluate the functioning and output of the EU as a state-like polity, but political parties, opinion-makers and social movements are increasingly mobilized on EU issues.

The articles by Rittberger and Kelemen explicitly address the political legitimacy, respectively, of the EU's legislative process and the legal system. Rittberger charts the process through which 'representative democracy', in the guise of a strong EP, 'assumed the status of a constitutional principle'. Member State governments, once strongly opposed to the principle, gradually acceded to it, even for matters with 'far-reaching [distributive] implications'. Kelemen shows that the judicialization of the EU has changed how democracy functions. In a mass of legislation adopted since the Single Act (1986), the Council of Ministers routinely enlisted the judiciary to help resolve the acute commitment problems of governing a decentralized, institutionally fragmented polity. Judicial authority, too, rests on templates of democratic legitimacy that are difficult for opponents to impugn (see Mény), including those associated with rights protection, access to justice and procedural transparency. The Rittberger and Kelemen articles comprise a powerful response to the assertion that the EU is afflicted with an acute democratic deficit that is incapable of being mitigated. As important, the probability that these outcomes will be reversed must be close to zero.

Is there a democratic deficit in the EU? Hobolt tackles this thorny question in a nuanced, state-of-the-art analysis of the public's 'satisfaction with democracy'. Overall, the majority of Europeans are satisfied with democracy in the EU - indeed, more so than they are 'with democracy in their own country' - though she finds wide cross-national variation. Relatively low levels of satisfaction with the EU are not explained by higher levels of confidence in national institutions; moreover, Hobolt 'found no evidence that economic growth or financial transfers [in themselves] boost satisfaction'. Instead, how 
citizens evaluate the representational and procedural aspects of EU democracy is crucial. Her conclusion, that the future of the public's views on the EU will depend on how well the regime is able 'to breed confidence in its democratic institutions', deserves to be considered in light of the research by Rittberger and Kelemen.

Two studies examine the politicization of the EU in detail. Fligstein et al. find support for theorists who predicted that a European identity would emerge among those who engage in transnational commerce and society, joined by other cosmopolitans. In 2010, a majority of people 'claimed a European identity at least some of the time'. National identity not only remains strong, but it is increasingly being defined, by a small but growing segment of the population, in opposition to immigration and to the EU. The outcome of a looming battle between the 'winners' of integration, who are heavily invested in the EU, and the 'losers', who are now partly organized into right-wing parties in the defence of insular nationalism, will partly determine the future.

In a complementary article, De Wilde and Zürn conceive politicization as a consequence of developments taking place since the Single Act of 1986. The more the EU impacts on national politics, they argue, the more integration will generate 'political mobilization and contestation'. As integration has proceeded, the EU's supranational institutions have been reconfigured to enhance the participation of individuals and organized interests (Héritier, Rittberger, Kelemen). At the national level, however, governments have sought to limit citizen involvement and contestation, especially after the failure to adopt an EU Constitution. De Wilde and Zürn argue that European integration has now gone too far for a strategy of 'depoliticization' to succeed.

Finally, Yves Mény, a long-time observer of and participant in EU affairs, offers concluding comments. He is gloomy about the current state of the Union, and pessimistic about its future. In moving beyond the goal of achieving a Common Market, the integration process has generated a number of intractable governance problems: the turn to Eurolegalism has not been counterbalanced by broadening citizen participation; the Commission remains dominated by an insular approach to consultation with affected interests; and the domain of national regulatory capacity and autonomy has steadily shrunk, while political representation and electoral politics remain stubbornly national. The current budgetary and monetary crisis shines a bright light on these problems (Eichengreen, Fligstein et al.), while revealing the striking absence of what Europe needs most: strong political leadership capable of forging a more federal EU. Although the regime has proved to be remarkably resilient in the face of past crises, Mény's cri de coeur reminds us again that regional integration constitutes a deeply political project.

\author{
Correspondence: \\ Walter Mattli \\ St Johns College \\ Oxford University \\ e-mail: walter.mattli@sjc.ox.ac.uk
}

Alec Stone Sweet

Law School and Department of Political Science

Yale University

e-mail: alec.sweet@yale.edu 


\section{References}

Abbott, F. (2000) 'NAFTA and the Legalization of World Politics: A Case Study'. International Organization, Vol. 54, No. 3, pp. 519-47.

Berrios Martinez, R.A. (1966) 'The Nature and Functioning of Article 177 of the Rome Treaty'. JCMS, Vol. 5, No. 2, pp. 113-39.

Bouzas, R. and Soltz, H. (2001) 'Institutions and Regional Integration: The Case of Mercosur'. In Bulmer-Thomas, V. (ed.) Regional Integration in Latin America and the Caribbean (London: Institute of Latin American Studies).

Burley, A.-M. and Mattli, W. (1993) 'Europe before the Court: A Political Theory of Legal Integration'. International Organization, Vol. 47, No. 1, pp. 41-76.

Caporaso, J.A. (1996) 'The European Union and Forms of State: Westphalian, Regulatory or Post-Modern?'. JCMS, Vol. 34, No. 1, pp. 29-52.

Cooley, A. and Spruyt, H. (2009) Contracting States: Sovereign Transfers in International Relations (Princeton, NJ: Princeton University Press).

Diab, M. (1966) 'The Arab Common Market'. JCMS, Vol. 4, No. 3, pp. 238-50.

Deutsch, K.W. (1963) 'Supranational Organizations in the 1960's'. JCMS, Vol. 1, No. 3, pp. $212-18$.

Fligstein, N. and Mara-Drita, I. (1996) 'How to Make a Market: Reflections on the Attempt to Create a Single Market in the European Union'. American Journal of Sociology, Vol. 102, No. 1 , pp. 1-33.

Fligstein, N. and Stone Sweet, A. (2002) 'Constructing Markets and Polities: An Institutionalist Account of European Integration'. American Journal of Sociology, Vol. 107, No. 5, pp. 1206-43.

Gallup (1963) 'Public Opinion and the European Community'. JCMS, Vol. 2, No. 2, pp. 101-26.

Garrett, G. (1992) 'International Cooperation and Institutional Choice: The European Community's Internal Market'. International Organization, Vol. 46, No. 2, pp. 533-60.

Gonzalez del Valle, J. (1966) 'Monetary Integration in Central America: Achievements and Expectations'. JCMS, Vol. 5, No. 1, pp. 13-26.

Griffin, K. and Ffrench-Davis, R. (1965) 'Customs Unions and Latin American Integration'. JCMS, Vol. 4, No. 1, pp. 1-21.

Haas, E. (1961) 'International Integration: The European and the Universal Process'. International Organization, Vol. 15, No. 3, pp. 366-92.

Haas, E. (1967) 'The Uniting of Europe and the Uniting of Latin America'. JCMS, Vol. 5, No. 2, pp. 319-20.

Haas, E. (1968) The Uniting of Europe: Political, Social and Economic Forces, 1950-1957, 2nd edn (Stanford, CA: Stanford University Press).

Haas, E. and Schmitter, P. (1964) 'Economics and Differential Patterns of Political Integration: Projections about Unity in Latin America'. International Organization, Vol. 18, No. 4, pp. 705-37.

Hall, P. (2011) 'Historical Institutionalism in Rationalist and Sociological Perspective'. In Mahoney, J. and Thelen, K. (eds) Explaining Institutional Change (Cambridge: Cambridge University Press).

Hooghe, L. and Marks, G. (2009) 'A Postfunctionalist Theory of European Integration: From Permissive Consensus to Constraining Dissensus'. British Journal of Political Science, Vol. 39, No. 1 , pp. 1-23.

Jupille, J., Mattli, W. and Snidal, D. (forthcoming) International Institutional Choice.

Krapohl, S, Faude, B. and Dinkel, J. (2010) 'Judicial Integration in the Americas? A Comparison of Dispute Settlement in NAFTA and MECOSUR'. In Laursen, F. (ed.) Comparative Regional Integration: Europe and Beyond (Farnham: Ashgate). 
JOBNAME: No Job Name PAGE: 16 SESS: 16 OUTPUT: Thu Nov 17 21:19:10 2011 SUM: 36894931

/v2451/blackwell/journals/JCMS_v50_is1/jcms_2224

Kim, S. and Shin, E.H. (2002) 'A Longitudinal Analysis of Globalization and Regionalization in International Trade: A Social Network Approach'. Social Forces, Vol. 81, No. 2, pp. 445-71.

Kitzinger, U. (1967) 'Britain's Crisis of Identity’. JCMS, Vol. 6, No. 4, pp. 334-58.

Lambert, J. (1966) 'The Constitutional Crisis, 1965-66'. JCMS, Vol. 4, No. 3, pp. 195-228.

Laursen, F. (2010) 'Requirements for Regional Integration: A Comparative Perspective of the EU, the Americas and East Asia'. In Laursen, F. (ed.).

Lindberg, L.N. (1967) 'The European Community as a Political System: Notes toward the Construction of a Model'. JCMS, Vol. 5, No. 4, pp. 344-87.

Majone, G. (2001) 'Two Logics of Delegation: Agency and Fiduciary Relations in EU Governance'. European Union Politics, Vol. 2, No. 1, pp. 103-22.

Marks, G., Hooghe, L. and Blank, K. (1996) 'European Integration from the 1980s: State-centric v. Multi-level Governance'. JCMS, Vol. 34, No. 3, pp. 341-78.

Mattli, W. (1999) The Logic of Regional Integration: Europe and Beyond (Cambridge: Cambridge University Press).

Mattli, W. and Slaughter, A. (1998) 'Revisiting the European Court of Justice'. International Organization, Vol. 52, No. 1, pp. 177-209.

McMahon, J.F. (1962) 'The Court of the European Communities'. JCMS, Vol. 1, No. 1, pp. $1-21$.

Mitrany, D. (1965) 'The Prospect of Integration: Federal or Functional'. JCMS, Vol. 4, No. 2, pp. 119-49.

Moravscik, A. (1993) 'Preferences and Power in the European Community: A Liberal Intergovernmentalist Approach'. JCMS, Vol. 31, No. 4, pp. 473-524.

Moravcsik, A. (1998) The Choice for Europe: Social Purpose and State Power from Massina to Maastricht (Ithaca, NY: Cornell University Press).

Navarrete, J.E. (1965) 'Latin American Economic Integration: A Survey of Recent Literature'. JCMS, Vol. 4, No. 2, pp. 168-77.

Peters, G., Pierre, G. and King, D. (2005) 'The Politics of Path Dependence: Political Conflict in Historical Institutionalism.' Journal of Politics, Vol. 67, No. 4, pp. 1275-1300.

Pierson, P. (1996) 'The Path to European Integration: A Historical-Institutionalist Analysis'. Comparative Political Studies, Vol. 29, No. 2, pp. 123-63.

Pollack, M. (1994) " "Creeping Competences”: The Expanding Agenda of the European Community'. Journal of Public Policy, Vol. 14, No. 2, pp. 95-145.

Pollack, M. (2003) The Engines of Integration: Delegation, Agency and Agency Setting in the European Union (Oxford: Oxford University Press).

Puchala, D.J. (1971) 'Of Blind Men, Elephants and International Integration'. JCMS, Vol. 10, No. 3, pp. 267-84.

Rosenstiel, F. (1963) 'Reflections on the Notion of "Supranationality" '. JCMS, Vol. 2, No. 2, pp. 127-39.

Sandholtz, W. (1996) 'Membership Matters: Limits of the Functional Approach to European Institutions'. JCMS, Vol. 34, No. 3, pp. 403-29.

Sandholtz, W. and Stone Sweet, A. (eds) (1998) European Integration and Supranational Governance (Oxford: Oxford University Press).

Scharpf, F. (1988) 'The Joint-decision Trap: Lessons from German Federalism and European Integration'. Public Administration, Vol. 66, No. 3, pp. 239-78.

Schneider, C. (2009) Conflict, Negotiations and EU Enlargement (Cambridge: Cambridge University Press).

Sidjanski, D. (1962) 'Voting Procedures in an Enlarged Community'. JCMS, Vol. 1, No. 2, pp. 173-9. 
Stone Sweet, A. (2010) 'The European Court of Justice and the Judicialization of EU Governance'. Living Reviews in European Governance, Vol. 5, No. 2, pp. 1-50. Available at «http:// www.livingreviews.org/lreg-2010-2».

Stone Sweet, A. and Brunell, T. (forthcoming) 'The European Court of Justice, State Noncompliance and the Politics of Override: Reply to Carruba, Gabel and Hankla'. American Political Science Review.

Stonham, P.E. (1967) 'Intra-regional Trade Co-operation in Developing Asia'. JCMS, Vol. 6, No. 2, pp. 197-210.

Swenden, W. (2004) 'Is the European Union in Need of a Competence Catalogue? Insights from Comparative Federalism'. JCMS, Vol. 42, No. 2, pp. 371-92.

Tallberg, J. (2006) Leadership and Negotiation the European Union (Cambridge: Cambridge University Press).

Thatcher, M. and Stone Sweet, A. (eds) (2002) 'The Politics of Delegation: Non-majoritarian Institutions in Europe'. Special Issue of West European Politics, Vol. 25, No. 1.

Thelen, K. (2004) How Institution Evolve (Cambridge: Cambridge University Press).

Triffin, R. (1965) 'International Monetary Arrangements, Capital Markets and Economic Integration in Latin America'. JCMS, Vol. 4, No. 1, pp. 70-104.

Von Krosigk, F. (1970) 'A Reconsideration of Federalism in the Scope of the Present Discussion on European Integration'. JCMS, Vol. 9, No. 3, pp. 197-23. 
JOBNAME: No Job Name PAGE: 18 SESS: 16 OUTPUT: Thu Nov 17 21:19:10 2011 SUM: 263377F9

/v2451/blackwell/journals/JCMS_v50_is1/jcms_2224

\begin{tabular}{|l|l|}
\hline \multicolumn{2}{|c|}{ SNP Best-set Typesetter Ltd. } \\
\hline Journal Code: JCMS & Proofreader: Elsie \\
\hline Article No: 2224 & Delivery date: 17 November 2011 \\
\hline Page Extent: 17 & \\
\hline
\end{tabular}

\section{AUTHOR QUERY FORM}

Dear Author,

During the preparation of your manuscript for publication, the questions listed below have arisen. Please attend to these matters and return this form with your proof.

Many thanks for your assistance.

\begin{tabular}{|c|c|c|}
\hline $\begin{array}{c}\text { Query } \\
\text { References }\end{array}$ & Query & Remark \\
\hline q1 & $\begin{array}{l}\text { AUTHOR: Spelling of author name Moravcsik does not } \\
\text { match the spelling in the Reference List, pls check and } \\
\text { advise. }\end{array}$ & \\
\hline $\mathrm{q}^{2}$ & $\begin{array}{l}\text { AUTHOR: Spelling of author name Swendon does not } \\
\text { match the spelling in the Reference List, pls check and } \\
\text { advise. }\end{array}$ & \\
\hline$q^{3}$ & $\begin{array}{l}\text { AUTHOR: Moravscik, A., } 1993 \text { has not been cited in the } \\
\text { text. Please indicate where it should be cited; or delete from } \\
\text { the Reference List. }\end{array}$ & \\
\hline$q^{4}$ & $\begin{array}{l}\text { AUTHOR: Swenden, W., } 2004 \text { has not been cited in the } \\
\text { text. Please indicate where it should be cited; or delete from } \\
\text { the Reference List. }\end{array}$ & \\
\hline
\end{tabular}

